\title{
Effect of using organic microminerals on performance and external quality of eggs of commercial laying hens at the end of laying ${ }^{1}$
}

\section{Mônica Patrícia Maciel ${ }^{2}$, Edilson Paes Saraiva², Édina de Fátima Aguiar ${ }^{3}$, Pedro Assunção Pimenta Ribeiro ${ }^{4}$, Débora Pereira Passos ${ }^{2}$, Jussara Barros Silva ${ }^{2}$}

\author{
1 Projeto financiado pela FAPEMIG. \\ 2 Departamento de Ciências Agrárias - UNIMONTES/Janaúba-MG. \\ ${ }^{3}$ Faculdade de Ciências Agrárias - UFVJM/Diamantina-MG. \\ ${ }^{4}$ Escola de Veterinária - UFMG/Belo Horizonte-MG.
}

ABSTRACT - The objective of the present study was to evaluate the effect of using microminerals in organic form on the performance and quality of eggs from commercial laying hens at the end of laying. Four hundred and eighty Hisex strain hens, 72 to 80 weeks of age, were used. A randomized complete design was used, with six replications and 16 birds for each experimental unit. Five diets were evaluated: basal feed supplemented with all microminerals in inorganic form (control); basal feed supplemented with 50\% microminerals zinc $(\mathrm{Zn})+$ manganese $(\mathrm{Mn})+$ copper $(\mathrm{Cu})$ in organic form and 50\% in inorganic form; basal feed supplemented with 50\% zinc in organic form and 50\% in inorganic form; basal feed supplemented with $50 \%$ manganese in organic form and 50\% in inorganic form; and basal feed supplemented with 50\% copper in organic form and $50 \%$ in inorganic form. There was no effect of diets on egg production, feed intake, food conversion and egg shell percentage and thickness. Birds fed basal feed supplemented only with zinc or manganese in organic form produced eggs with lower specific weight. The use of basal feed supplemented with copper in organic form has minimized egg loss. However, the best results (lower egg loss, higher specific weight and higher weight of eggs) were obtained with the basal feed supplemented with microminerals $\mathrm{Zn}+\mathrm{Mn}+\mathrm{Cu}$ in organic form and, therefore, it is recommended for feeding of commercial laying at the end of laying.

Key Words: egg characteristics, laying hens, minerals, production

\section{Efeito da utilização de microminerais orgânicos sobre o desempenho e a qualidade externa dos ovos de poedeiras comerciais em final de postura}

\begin{abstract}
RESUMO - Um experimento foi realizado com o objetivo de avaliar o efeito da utilização de microminerais na forma orgânica sobre o desempenho e a qualidade dos ovos de poedeiras comerciais em final de postura. Foram utilizadas 480 galinhas da linhagem Hisex com 72 a 80 semanas de idade, distribuídas em delineamento inteiramente casualizado, com 6 repetições e 16 aves por parcela. Foram avaliadas cinco dietas: ração basal suplementada com todos os microminerais na forma inorgânica (controle); ração basal suplementada com 50\% dos microminerais zinco (Zn) + manganês (Mn) + cobre (Cu) na forma orgânica e 50\% na forma inorgânica; ração basal suplementada com 50\% de zinco na forma orgânica e 50\% na forma inorgânica; ração basal suplementada com $50 \%$ de manganês na forma orgânica e 50\% na forma inorgânica e ração basal suplementada com 50\% de cobre na forma orgânica e 50\% na forma inorgânica. Não houve efeito das dietas sobre a produção de ovos, o consumo de ração, a conversão alimentar, a porcentagem e a espessura de casca. As aves que consumiram a ração basal suplementada apenas com zinco ou manganês na forma orgânica produziram ovos com menor peso específico. A utilização da ração basal suplementada com cobre na forma orgânica proporcionou menor perda de ovos. Porém, os melhores resultados foram obtidos com a ração basal suplementada com os microminerais $\mathrm{Zn}+\mathrm{Mn}+\mathrm{Cu}$ na forma orgânica, pois proporcionou menor perda de ovos, maior peso específico e maior peso dos ovos, sendo, portanto, recomendada para a alimentação de poedeiras comerciais em final de postura.
\end{abstract}

Palavras-chave: características dos ovos, minerais, poedeiras, produção

\section{Introduction}

Organic minerals or chelated minerals have been studied by several researchers because they may present better bioavailability than inorganic minerals. According to AAFCO (1997), organic minerals are metal ions chemically linked to an organic molecule (aminoacids), forming chemical structures with unique characteristics of stability and high mineral bioavailability. When chelated correctly, microminerals are absorbed and used by the 
animals at higher proportions than the minerals present in food or in mineral supplements. Absorption of almost $100 \%$ of chelated minerals reduces the animals' mineral requirements.

Results reported in the literature prove that the information about organic minerals is still controversial. In an experiment to evaluate organic sources of zinc ( $\mathrm{Zn})$, manganese $(\mathrm{Mn})$ and copper $(\mathrm{Cu})$ alone or in combination, Paik (2001) observed an enhancement in egg production from hens that received the source with organic copper only and from those that received the combination of the three minerals. The egg shell quality was higher when zinc was supplied in its chelated form. However, Mabe (2003) did not observe difference between microminerals in organic or inorganic forms when related to the percentage of shell or to the shell weight by unit of surface area. The addition of microminerals in organic form slightly decreased the egg weight, but increased the resistance of the egg shell from the birds older than 60 weeks. Sechinato (2003) did not observe an enhancement in egg production and quality with the use of organic $\mathrm{Zn}$, Mn, selenium, $\mathrm{Cu}$, iodine and iron compared with the inorganic forms. Nevertheless, isolated supplementation of each organic micromineral in feed had worsened the results compared to supplementation with organic microminerals alone or with inorganic microminerals alone.

The objective of the present study was to evaluate the effect of using organic microminerals on egg performance and external quality from commercial laying hens at the end of laying.

\section{Material and Methods}

The experiment was conducted on Somai Nordeste S/A farm, in Montes Claros, northern Minas Gerais, Brazil. The experimental period lasted 9 weeks, corresponding to the 72 to 80 weeks of age of the birds.

Four hundred and eighty Hisex strain light laying hens were used, housed in a conventional laying shed with eating troughs and nipple type drinking troughs, one trough for every two cages, with a density of 4 birds per cage. A thermometer was installed in the center of the shed from which maximum and minimum temperatures were obtained daily. Lighting was by fluorescent 40W lamps and a 16-hour light period was used.

Treatments consisted of five different diets: basal feed supplemented with all microminerals in inorganic form (control); basal feed supplemented with 50\% zinc, manganese and copper minerals in organic form and $50 \%$ in inorganic form; basal feed supplemented with 50\% zinc in organic form and $50 \%$ in inorganic form; basal feed supplemented with 50\% manganese in organic form and 50\% in inorganic form; basal feed supplemented with $50 \%$ copper in organic form and 50\% in inorganic form. The diets used (Table 1) consisted mainly of corn and soy bran, isoproteic (16.0\% CP) and isocaloric (2,830 kcal ME/kg), formulated to meet the nutritional requirements established for the Hisex strain (Interaves, 2009) adapted to farm conditions. Minerals were supplemented per $\mathrm{kg}$ of feed (Table 2).

A randomized complete design was used, with five treatments and six replications, totaling 30 plots. Each plot consisted of four cages, each one with four birds, totaling 16 birds per experimental unit.

The following characteristics were evaluated: feed intake (g/bird/day), food conversion (g feed/g egg), production (\% eggs/bird/day), eggs weight (g), egg loss (broken and cracked eggs - \%), specific weight, egg shell thickness (mm) and egg shell percentage (g/g), all recorded weekly. For specific weight evaluation, every intact egg produced was collected, seven saline solutions were used, with 1,066 to $1,090 / \mathrm{cm}^{3}$ density and 0.004 gradient among them. Egg shell thickness was evaluated using three eggs per plot, obtaining the reading by micrometer of three points in the equatorial region of the egg, and the egg shell percentage was obtained by the ratio between egg shell weight/egg weight.

Data was submitted to analysis of variance and the means obtained were evaluated by the Scott-Knot test $(\mathrm{P}<0.05)$ using the SISVAR computational package, described by Ferreira (2000).

\section{Results and Discussion}

No significant differences $(\mathrm{P}>0.05)$ were observed in the results of egg production, feed intake and food conversion with the supplementation of feed with microminerals in organic form. However, an effect $(\mathrm{P}>0.05)$ was observed of the supplementation on egg weight and loss (Table 3).

Most of the studies in the literature do not report effects of organic minerals on production, feed intake and food conversion (Kienholz, 1992; Dale \& Strong, 1998; Ludeen, 2001; Sechinato, 2006), with the exception of Branton et al. (1995), who observed an improvement in laying percentage of birds that received chelated minerals. Paik (2001) observed an increase in laying rate of birds 96 to 103 weeks of age that received organic copper and the association of organic $\mathrm{Cu}+\mathrm{Mn}+\mathrm{Zn}$. 
Table 1 - Composition of experimental diets

\begin{tabular}{|c|c|c|c|c|c|}
\hline \multirow[t]{2}{*}{ Ingredient } & \multicolumn{5}{|c|}{ Diet $(\%)$} \\
\hline & $\begin{array}{l}\text { Basal feed }+\mathrm{Zn}, \\
\mathrm{Mn} \text {, Cu (inorganic) }\end{array}$ & $\begin{array}{c}\text { Basal feed }+ \\
\text { Mn, Cu (organic) }\end{array}$ & $\begin{array}{c}50 \% \text { Zn,Basal feed + } \\
50 \% \text { Zn (organic) }\end{array}$ & $\begin{array}{c}\text { Basal feed }+ \\
50 \% \text { Mn (organic) }\end{array}$ & $\begin{array}{c}\text { Basal feed }+50 \% \\
\text { Cu (organic) }\end{array}$ \\
\hline Soy bran & 16.118 & 16.055 & 16.672 & 16.080 & 16.121 \\
\hline Oyster flour & 2.000 & 2.000 & 2.000 & 2.000 & 2.000 \\
\hline Calcitic limestone & 7.244 & 7.238 & 7.240 & 7.238 & 7.238 \\
\hline Alimet (liquid methionine) & 0.067 & 0.066 & 0.060 & 0.066 & 0.066 \\
\hline Salt & 0.269 & 0.269 & 0.268 & 0.269 & 0.274 \\
\hline Lysine & 0.052 & 0.054 & 0.034 & 0.054 & 0.052 \\
\hline Vitamin supplement ${ }^{1}$ & 0.100 & 0.100 & 0.100 & 0.100 & 0.100 \\
\hline Mineral supplement & 0.050 & - & - & - & - \\
\hline \multicolumn{6}{|l|}{ Calculated composition } \\
\hline Available phosphorus (\%) & 0.36 & 0.36 & 0.36 & 0.36 & 0.36 \\
\hline Sodium (\%) & 0.16 & 0.16 & 0.16 & 0.16 & 0.16 \\
\hline Linoleic acid (\%) & 1.00 & 1.00 & 1.00 & 1.00 & 1.00 \\
\hline Choline (mg/kg) & 874.20 & 874.20 & 874.20 & 874.20 & 874.20 \\
\hline Methionine (\%) & 0.31 & 0.31 & 0.31 & 0.31 & 0.31 \\
\hline Methionine + cystine (\%) & 0.54 & 0.54 & 0.54 & 0.54 & 0.54 \\
\hline Lysine (\%) & 0.72 & 0.72 & 0.72 & 0.72 & 0.72 \\
\hline
\end{tabular}

${ }^{1}$ Composition/kg: vit. A, 6,000,000 UI; vit. $\mathrm{D}_{3}, 1,650,000 \mathrm{UI}$; vit. E, 20,000 UI; vit. $\mathrm{K}_{3}, 1.35$ mg; vit. $\mathrm{B}_{2}$, 3 mg; vit. $\mathrm{B}_{6}, 1.478$ mg; vit. $\mathrm{B}_{12}$, 7,500 mg; niacin, 20 g; folic acid, $0.498 \mathrm{~g}$; calcium pantothenate, $12.5 \mathrm{~g}$; biotin, $0.100 \mathrm{~g}$.

Table 2 - Supplemented minerals in the experimental diets (mg/kg)

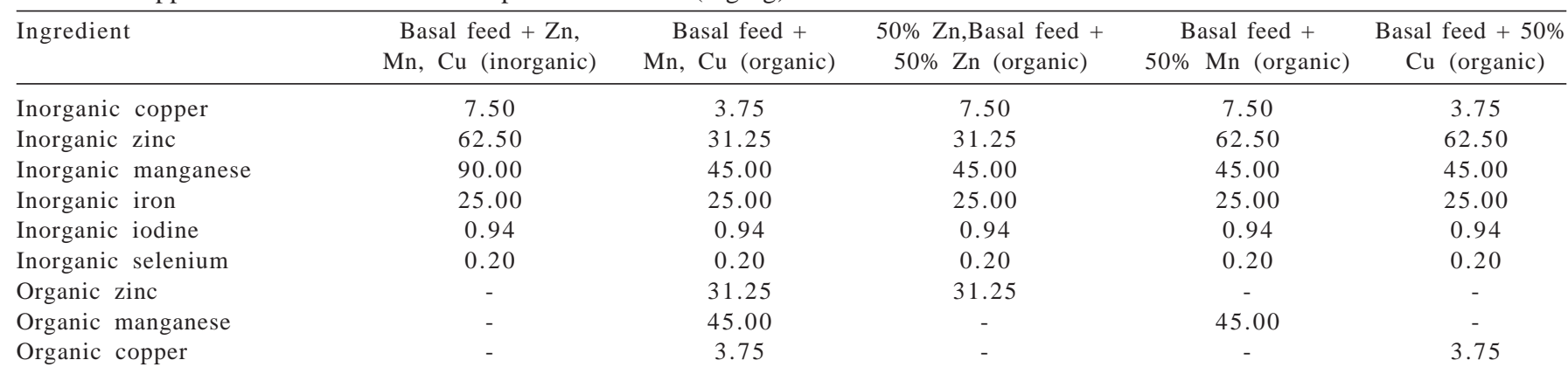

Birds that received feed supplemented with $50 \%$ organic $\mathrm{Zn}+\mathrm{Cu}+\mathrm{Mn}$ produced heavier eggs. This result may have been due to a combined action of the three microminerals used, since they are directly associated to egg formation (Underwood, 1999). Zinc is one of the constituents of carbonic anhydrase, an enzyme involved in egg shell formation (Leeson \& Summers, 2001); manganese is the metal activator of enzymes that are involved in the synthesis of mucopolysaccharides and glycoproteins that contribute to the formation of the organic matrix of the shell (Georgievski, 1982); and according to Scott et al. (1982), copper plays the role of cofactor of the lysyl-oxylase enzyme that is important in the formation of collagen cross-links present in the egg shell membrane.
The results obtained for egg weight differed from those reported by Sechinato (2003), who did not observe an enhancement in this variable when supplied feed containing several associated organic microminerals or feed with those microminerals separately. Paik (2001) observed an enhancement in egg weight when supplied feed containing only chelated zinc compared to feed containing only organic microminerals and to feed containing the association of organic zinc and manganese.

There was less eg

g loss from the birds that received feed supplemented with organic zinc+copper+manganese and feed supplemented with 50\% copper in organic form. These results corroborated with those from Mabe et al. (2003) who 
Table 3 - Means of egg production, feed intake, egg weight, food conversion and egg loss obtained with the experimental diets*

\begin{tabular}{lccccc}
\hline Diet & Egg production (\%) & Feed intake (g) & Egg weight (g) & Food conversion (g/g) & Egg loss (\%) \\
\hline Basal feed + Zn, Mn, Cu (inorganic) & 74.21 & 105.77 & $66.34 \mathrm{~B}$ & 1.59 & $8.90 \mathrm{~A}$ \\
Basal feed + 50\% Zn, Mn, Cu (organic) & 72.38 & 107.01 & $68.16 \mathrm{~A}$ & 1.57 & $6.93 \mathrm{~B}$ \\
Basal feed + 50\% Zn (organic) & 74.41 & 106.83 & $66.55 \mathrm{~B}$ & 1.61 & $10.30 \mathrm{~A}$ \\
Basal feed + 50\% Mn (organic) & 74.80 & 105.18 & $67.12 \mathrm{~B}$ & 1.57 & $9.54 \mathrm{~A}$ \\
Basal feed + 50\% Cu (organic) & 72.89 & 105.69 & $66.61 \mathrm{~B}$ & 1.59 & $5.60 \mathrm{~B}$ \\
Mean & 73.74 & 106.10 & 66.96 & 1.59 & 8.25 \\
CV (\%) & 9.07 & 3.33 & 2.55 & 4.06 & 57.43 \\
\hline
\end{tabular}

${ }^{*}$ Means followed by different lowercase letters in the same column differ statistically by the Scott-Knott test $(\mathrm{P}<0.05)$.

observed a slight increase in egg shell resistance in birds with 60 and more weeks of age that received zinc, manganese and copper in organic form. Sechinato (2003) also verified better results with the combined use of these microminerals in organic form in feed.

The best result found with using copper in organic form may be related to its influence in the formation of the egg shell membrane, which may have contributed to higher resistance, generating fewer losses. Nevertheless, there is no data in the literature that relates the resistance of this membrane to smaller egg loss by breaking or cracking.

Another factor that may have contributed to the smaller egg loss was the fact that the minerals were chelated, mainly copper, because it is antagonist to zinc, meaning that, copper inhibits zinc digestion and absorption because it favors the proportion of soluble zinc associated to large complexes (Pang et al., 2007).

Feed supplementation with organic microminerals did not influence $(\mathrm{P}>0.05)$ the percentage and shell thickness. However, supplementation affected $(\mathrm{P}>0.05)$ the specific weight of the eggs (Table 4).

Similar results to the present study were observed by Moreng (1992), Balnave \& Zhang (1993), Dale \& Strong (1998), Mabe et al. (2003) and Utterback et al. (2005), who also did not observe an improvement in egg shell thickness and percentage from laying hens supplied with different organic sources of microminerals. However, Rutz et al. (2004) observed enhancement in shell thickness as an effect of organic zinc and manganese supplementation in diets for laying hens. That divergence of results may be explained by the fact that this author had used semi heavy weight hens (Isa-Brown strain), which may present different responses than light weight hens, the ones used in this research.

The use of basal feed supplemented only with inorganic microminerals provided specific weight results similar to the results obtained with basal feed with organic $\mathrm{Zn}+\mathrm{Mn}+\mathrm{Cu}$ and with basal feed with organic copper. This result was not expected, because there were no differences among feeds for thickness and shell percentage that are highly correlated with specific weight (Abdallah et al., 1993). These results differed from those observed by Paik (2001) who verified enhancement in egg specific weight from birds supplied with copper, manganese and zinc in organic form. Mabe (2003), however, when evaluating the inorganic and organic form of zinc and manganese supplementation, did not find enhancement in the egg quality parameters, corroborating with Dale \& Strong (1998), who also did not obtain enhancement in egg quality with the use of those organic microminerals.

The difference between the results obtained in the present research and results reported in the literature may be explained, in part, by the great variety of chelated molecules on the market and their differences in bioavailability and stability, as well their metabolism in the animal organism.

Table 4 - Means of egg shell percentage, egg shell thickness and egg specific weight obtained with the experimental diets

\begin{tabular}{lcc}
\hline Diet & Egg shell percentage (\%) & Egg shell thickness (mm) \\
\hline Basal feed + Zn, Mn, Cu inorganic & 11.15 & 0.381 \\
Basal feed + 50\% Zn, Mn, Cu organic & 11.21 & 0.386 \\
Basal feed + 50\% Zn organic & 11.13 & 0.384 \\
Basal feed + 50\% Mn organic & 11.16 & 0.383 \\
Basal feed + 50\% Cu organic & 11.10 & 0.392 \\
Mean & 11.15 & 0.385 \\
CV (\%) & 5.53 & $1.0819 \mathrm{~B}$ \\
\hline
\end{tabular}

* Means followed by different uppercase letters in the same column differ statistically by the Scott-Knott test $(\mathrm{P}<0.05)$. 


\section{Conclusions}

The use of a basal feed supplemented with $50 \%$ zinc, manganese and copper in organic form presented better results providing, at the same time, greater egg weight, higher specific weight and lower percentage of egg loss from commercial laying hens.

\section{References}

ASSOCIATION OF AMERICAN FEED CONTROL OFFICIALS AAfCO. Official Publication. Atlanta: 1997. 101p.

ABDALlAH, A.G.; HARMS, R.H.; EL-HUSSEINY, O. Various methods of measuring shell quality relation to percentage of cracked eggs. Poultry Science, v.72, n.11, p.2038-2043, 1993.

BALNAVE, D.; ZHANG, D. Response of laying hens on saline drinking water to dietary supplementation with various $\mathrm{Zn}$ compounds. Poultry Science, v.72, p.603-609, 1993.

BRANTON, S.L.; LOTT, B.D.; MASLIN, W.R. et al. Fatty liverhemorrhagic syndrome observed in commercial layers fed diets containing chelated minerals. Avian Diseases, v.39, p.631-635, 1995.

DALE, N.; STRONG JR., C.F. Inability to demonstrate an effect of eggshell 49 on shell quality in older laying hens. Applied Poultry Science, v.7, p.219-224, 1998.

FERREIRA, D.F. SISVAR - Sistema de análise estatística para dados balanceados. Lavras: UFLA/DEX, 2000. (Software).

GEORGIEVSKI, V.I. Mineral nutrition of animals. London: Butterworts, 1982. 475p.

KIENHOLZ, E.W. Zinc methionine for stressed laying hens. Poultry Science, v.71, p.829-832, 1992.

LEESON, S.; SUMMERS, J.D. Nutrition of the chickens. 4.ed. Guelph: University Books, 2001. 591p.

LUDEEN, T. Mineral proteinates may have positive effect on shell quality. Feedstuffs, v.73, n.14, p.10-15, 2001.

MABE, I.; RAPP, C.; BAIN, M.M. et al. Supplementation of a corn-soybean meal diet with manganese, copper, and zinc from organic or inorganic sources improves eggshell quality in aged laying hens. Poultry Science, v.82, p.1903-1913, 2003.

INTERAVES. Manual de manejo Hisex White. 2006 Disponível em: <http://www2.globoaves.com.br/?id=8>. Acesso em: 15/1/2007.

MORENG, R.E. Dietary zinc methionine effect on shell quality of hens drinking saline water. Poultry Science, v.71, p.1163-1167, 1992.

PAIK, I. Application of chelated minerals in animal production. Asian-Australasian Journal of Animal Science, v.14, p.191-198, 2001.

PANG, Y.; APPLEGATE, T.J. Effects of dietary copper supplementation and copper source on digesta ph, calcium, zinc, and copper complex size in the gastrointestinal tract of the broiler chicken. Poultry Science, v.86, p.531-537, 2007.

ROLAND, D.A. Recent developments in egg shell quality. Feed Stuffs, v.48, n.29, p.31, 1976.

RUTZ, F.; ANCIUTI, M.A.; RECH, J.L. et al. The impact of organic minerals on performance of poultry. In: Annual Australian Poultry Science Symposium, Sydney/Austrália, v.1, n.1, p.71-74, 2004.

SECHINATO, A.S. Efeito da suplementação dietética com microminerais orgânicos na produção e qualidade de ovos de galinhas poedeiras. 2003. 68f. Dissertação (Mestrado em Nutrição Animal) - Universidade de São Paulo, Pirassununga.

SECHINATO, A.S.; ALBUQUERQUE, R.; NAKADA, S. Efeito da suplementação dietética com micro minerais orgânicos na produção de galinhas poedeiras. Brazilian Journal of Veterinary Research and Animal Science, v.43, p.159-166, 2006.

SCOTT, M.L.; NESHEIM, M.C.; YOUNG, R.G. Nutrition of the chicken. 3.ed. Ithaca: ML Scott and Associates, 1982. $562 \mathrm{p}$.

UNDERWOOD, E.J. The mineral nutrition of livestock. 3.ed. Wallingford: CABI, 1999. 614p.

UTTERBACK, P.L.; PARSONS, C.M.; YOON, I. et al. Effect of supplementing selenium east in diets of laying hens on egg selenium content. Poultry Science, v.84, p.1900-1901, 2005. 